renewal fees which the applicant must pay to the national patent offices in the designated countries to keep the patent alive (half of these fees are returned to the EPO).

The survey concludes that it is still cheap$\mathrm{er}$, as intended in the European Patent Convention of 1973 , for a company to patent an invention through the EPO, designating protection in the three largest member countries - namely the United Kingdom, Germany and France - than filing individually in the three countries. This is primarily because only one set of attorney fees is involved, instead of three. But the margin is only six per cent.

The survey found that the average cost of filing a patent in the United States or Japan is around 20 per cent cheaper than the EPO. This is because, although the attorney fees are much lower in Europe, the official patent office fees, at DM9,900, are at least three times as high.

Another major item of expenditure for European patents that is not shared by Japan and the United States is translation costs. Patent applications can be submitted in one of the three EPO official languages, namely English, French or German, with the summarized claims being translated into the other two languages on publication.

But EPO member states insist that any EPO patent given protection in their country must be translated in full into the national language. This means that for an average patent, covering eight designated member states, translation costs constitute on average DM15,200, or one-third of the total cost.

The EPO is keen to reduce the costs associated with translation. But doing so requires the political agreement of its member states. Although translations have no legal status, attempts in the past to eliminate their requirement have been resisted by member states, who insist that it is the only way to guarantee their citizens full access to patent information.

The EPO administrative council has highlighted suggestions for cost saving in a discussion document made public last week. The document invites comments from both researchers and industrial representatives on other cost-saving proposals, such as reducing the duplication of work between the EPO and national patent offices, for example by centralizing of some activities such as translation.

Another suggestion would be to devolve responsibility for activities such as searches to the larger national offices. But this is a politically-sensitive issue because of the continuing power struggle between the national and European offices.

Furthermore, any conclusions based on the comments received could take a considerable time to implement. As EPO staff members despairingly note, the conflicting interests of member states have frequently in the past prevented apparently obvious solutions to the EPO's problems from being introduced.

Alison Abbott

\title{
Chirac downgrades science in re-shuffle of ministries
}

Paris. The incoming government of France's new president, Jacques Chirac, has stunned the country's researchers by abolishing France's independent science ministry. The change ends the prominent political status given to research under France's Socialist president François Mitterrand during his 14-year period of office.

"It's a step backwards of about 20 years for research," said one leading French research official in reaction to news that the administration of Alain Juppé, the new Prime Minister, will fold research into a superministry of "national education, higher education, research and social insertion".

Under the governments of Mitterrand, research terrand, research concerns over CNRS.

\section{IMAGE UNAVAILABLE FOR COPYRIGHT REASONS} ministry, or was combined with higher education or with industry. Observers fear that the new arrangements could result in research being neglected because of the enormous day-to-day demands of the school and higher education portfolios.

The nomination of a secretary of state for research has done little to allay such concerns. Unlike ministers and junior ministers, secretaries of state do not routinely attend cabinet meetings, for example.

Moreover, while research was run by a secretary of state under Giscard d'Estaing's presidency during the $1970 \mathrm{~s}$, the post was directly attached to the prime minister. It is now attached to the education ministry.

The lack of a cabinet minister dedicated to research could, in particular, damage France's ability to develop both a national strategy for research, and its international policy, particularly in Brussels, argues Pierre Papon, chairman of the Observatoire de Science et Technologie, and a former head of the Centre National de la Recherche Scientifique (CNRS).

Moreover, the new secretary of state, Elisabeth Dufourcq, 54, is relatively unknown in science policy circles. She is a researcher at INSERM, the national biomedical research agency, a member of the national bioethics advisory committee, and a historian who has published several books on women missionaries.

Observers argue that while the appointment of a secretary of state for research may improve day-to-day management of the research portfolio, Dufourcq lacks the political clout of past research ministers such as François Fillon or JeanPierre Chevènement - who were both career politicians.

Nor will she start her new role with the reputation of the geophysicist Hubert Curien, who, although not a politician by profession, had headed both the French space agency (CNES) and CNRS, and was considered to be more wily than many professional politicians.

Some fear that the lack of such political punch will mean bad news for research, particularly when budget levels need to be negotiated with the powerful finance ministry. "My overall impression [of the new ministerial configuration] is that the political weight of research has been very strongly diminished," says one observer.

Edouard Brezin, the president of CNRS, argues that it is too soon to judge the new government's commitment to research. Although admitting that he would have been "more reassured" by an independent research ministry, he says he "hopes research will be one of the government's priorities."

In contrast, the SNCS, one of the labour unions that represent researchers, criticized the "drowning" of research within the new "superministry", as "a bad omen for the attitude of the new government to research".

While some argue that research is unlikely to face the harsh cuts it experienced when Chirac was prime minister in 1986, few believe he will keep his campaign promise to increase research spending.

They point out that during his election campaign, Chirac stated in an interview with $L a$ Recherche magazine that he favoured a dedicated research ministry, arguing that while the links between research and the universities were important, research had many aspects, and went far beyond the university.

The new minister who will hold ultimate political responsibility for research is François Bayrou, who was also minister of national education in the previous government. Bayrou visited CNRS headquarters last weekend immediately after his nomination, along with Dufourcq, in what is being seen as an attempt to allay concerns over the future of the cash-strapped agency (see Nature 374, 666, 1995). "Research will be at the centre of my preoccupations", he said, adding that he intended to make regular visits to CNRS.

Bayrou emphasized the "tight links" between research and education. He added that CNRS "assumes one of the grand functions of the nation, and is at the heart of one of the grand ministries of the Republic: this is a message of respect, and, I hope, of hope."

Declan Butler 